\title{
CHARACTERIZING THE IMPACT OF ORGANIZATIONAL CULTURE ON THE MANAGER LEADERSHIP QUALITIES
}

\begin{abstract}
The article presents the outcomes of sociological research to identify: the influence of organizational culture on the managers' leadership qualities and the interdependence of management style and leader's personality type of the Saint-Petersburg social services and organizations. It was revealed that the organizational culture type in the considered social institutions has a bureaucratic character; authoritarian management style predominates; the majority of branch managers are leaders with organizational skills.

It is determined that the passionate manager's personality type controls organization in an innovative-analytical style, which contributes to a greater activity efficiency. Such leaders are active, focusing on innovative work methods, encourage innovation, modern technologies and high performance, successfully apply brainstorming.

Thus, the manager's personality integral model is empirically tested and substantiated through sociological research.

Keywords: manager's personality integral model, personality type, organizational culture type, management style, leadership qualities, innovative and analytical management style, authoritarian style, Saint-Petersburg social institutions.
\end{abstract}

Introduction

A conceptual analysis of the manager's personality integral theory implies not only effective management model elements (manager's personality type, organizational culture type and management style), but also the development of the manager's personality in the Russian sociological management concept, in particular, the features of the leader's personality, his behavior, activity are considered in the works of the following authors: the role of personality enneagram in the control system (Aleshin, 2015); personality value indicators and manager's activity (Bushkova-Shiklina, 2012); individual's elite-oriented activities in management system (Karabushenko, 2013); the leader's identity and the motivation of his activities (Klukovkin, 2008); theoretical foundations of social regulation of managerial type (Tikhonov, 2009).

The leadership problem has long been a keen interest of sociologists and psychologists, both foreign and domestic. Scientists focus on the leadership moral aspects (Koestenbaum, 1991), and the issues of the interdependence 
between organizational culture and management features (Shejn, 2002), mechanisms for developing leadership in a group and organization (Fiedler, 1972; Tannenbaum, 1962).

The problem of identifying the leadership optimal style was touched upon in domestic psychology (Zhuravlev, 2004).

The phenomenon of "organizational culture" has become an object of analysis among many foreign authors and researchers (Anchtoff, 1989; Dessler, 2003; Shejn, 2002), we also would single out K. S. Kameron and R. E. Quinn's (2001) "Diagnosis and Change in Organizational Culture", because it determines the direction to improve the manager's organizational culture for successful outcomes of the organization.

In the domestic literature, the concept of "organizational culture" began to be covered relatively recently in comparison with Western literature (Korotkov, 2002; Aleshina \& Zaglada, 2016; Oganyan, K. M., 2013).

The analysis of the above mentioned showed the need to create the author's integral theory of leader identity by developing a threecomponent model of effective management.

The importance of leadership is increasing in the modern world, along with the increasing role of organization management. Various seminars and training are held, aiming to develop leadership skills among future leaders. However, in organizations, there are more and more employees who perform the leader's functions in the team with an effect on the team's members along with a formal leader. Leaders can both interfere with a real leader, and improve the "climate" in the organization (Oganyan, K. K., 2014).

The leader should rationally manage both the production and organization social compo- nents. Nevertheless, the presence of a leader is not an indicator of stability and success; an important aspect here is its quality characteristics. All these qualitative characteristics of the manager's activity are reflected in management style and organizational culture type. It is these three components - leader's personality type, management style and organizational culture type that are the basic model components for effective organization management. (Oganyan, K. K., 2015). This theoretical model was developed by us and was empirically verified and substantiated by the conducted sociological researches at the Universities of Saint-Petersburg and regions (Oganyan, K. K., 2016), and within the framework of this article - in social institutions and organizations of St. Petersburg.

\section{Some Characteristics of the Research Base $^{1}$}

Center 1: The St. Petersburg State Budgetary Institution "DSS TsSPiSD Petrogradsky district St. Petersburg" (see Table 1).

The institution was created to achieve the following goals:

- social service for families with minor children in difficult life situations;

- families in extreme situations;

- families who have adopted orphans and children left without parental care for upbringing;

- minors in socially dangerous position;

- teen-age (adolescent) mothers with babies, and pregnant teenagers;

The sociological research was conducted at the Center for Social Assistance to Families and Children of the Petrogradsky District of St. Petersburg and the Center for the Social Rehabilitation of Disabled People and Disabled Children of the Petrogradsky District of St. Petersburg. 
- minors left without parental care, orphans and children left without parental care, aged from 18 to 23 in difficult life situations;

- women affected by any form of violence;

- refugees and internally displaced persons in difficult life situations; HIV-infected citizens and their families, citizens dependent on psychoactive substances, in need of social services (hereinafter referred to as recipients of social services).

Table 1 .

Center 1. Institution Structure

\begin{tabular}{|c|c|}
\hline Branch Name & Branch Structure \\
\hline $\begin{array}{l}\text { Administrative and Management Personnel } \\
\text { (AMP) }\end{array}$ & $\begin{array}{l}\text { - Director } \\
\text { - Deputy Director for Social Affairs } \\
\text { - Chief Accountant } \\
\text { - Human Resources Specialist } \\
\text { - Document Manager } \\
\text { - Economist } \\
\text { - Head of the Administrative and Economic Affairs } \\
\text { - Legal Counsel }\end{array}$ \\
\hline $\begin{array}{l}\text { Citizen Reception and Consultation Depart- } \\
\text { ment }\end{array}$ & $\begin{array}{l}\text { - Head of the Department } \\
\text { - Social Work Specialist }\end{array}$ \\
\hline $\begin{array}{l}\text { The Department for the Prevention of the Mi- } \\
\text { nor Neglect }\end{array}$ & $\begin{array}{l}\text { - Head of the Department } \\
\text { - Social Work Specialist } \\
\text { - Tutor }\end{array}$ \\
\hline $\begin{array}{l}\text { Organizational and Methodological } \\
\text { Department }\end{array}$ & $\begin{array}{l}\text { - Head of the Department } \\
\text { - Sociologist } \\
\text { - Secretary } \\
\text { - Programmer }\end{array}$ \\
\hline $\begin{array}{l}\text { The Department of Psychological, Pedagogi- } \\
\text { cal and Legal Assistance }\end{array}$ & $\begin{array}{l}\text { - Head of the Department } \\
\text { - Psychologist } \\
\text { - Lawyer } \\
\text { - Organizer of Socializing Activity } \\
\text { - Teacher of Further (Additional) Education }\end{array}$ \\
\hline Department of Social Assistance to Citizens & $\begin{array}{l}\text { - Head of the Department } \\
\text { - Social Work Specialist } \\
\text { - Psychologist }\end{array}$ \\
\hline Social Hotel for Minors & $\begin{array}{l}\text { - Head of the Department } \\
\text { - Specialist in Social Work } \\
\text { - Teacher Dealing with Social Work } \\
\text { - Barmaid } \\
\text { - Psychologist } \\
\text { - Office Cleaner } \\
\text { - Linen Keeper }\end{array}$ \\
\hline
\end{tabular}

Center 2: The St. Petersburg State Budgetary Institution of Emergency Situations "TsSRIIDI of the Petrogradsky District of St. Petersburg" (see Table 2).
The institution was created to achieve the following goal: social services for the disabled adults and children. 
Table 2.

Center 2. Structure

\begin{tabular}{|c|c|}
\hline Branch Name & Branch Structure \\
\hline $\begin{array}{l}\text { Administrative and Management Personnel } \\
\qquad(\text { AUP) }\end{array}$ & $\begin{array}{l}\text { - Director } \\
\text { - Deputy Director for Social Rehabilitation Issues } \\
\text { - Accountant - Economist } \\
\text { - HR Specialist } \\
\text { - Head Manager }\end{array}$ \\
\hline $\begin{array}{l}\text { Organizational and Methodological } \\
\text { Department }\end{array}$ & $\begin{array}{l}\text { - Head of the Department } \\
\text { - Specialist Dealing with Social Work }\end{array}$ \\
\hline Day Care Department for Disabled Children & $\begin{array}{l}\text { - Head of the Department } \\
\text { - Social Work Specialist } \\
\text { - Organizer of Cultural Activities }\end{array}$ \\
\hline $\begin{array}{l}\text { Social Rehabilitation Department for Disabled } \\
\text { Children }\end{array}$ & $\begin{array}{l}\text { - Head of the Department } \\
\text { - Specialist in Social Work } \\
\text { - Speech Therapist - Defectologist } \\
\text { - Psychologist }\end{array}$ \\
\hline $\begin{array}{l}\text { Day Care Department for Disabled People of } \\
\text { Working Age }\end{array}$ & $\begin{array}{l}\text { - Head of the Department } \\
\text { - Social Work Specialist } \\
\text { - Organizer of Social Activities } \\
\text { - Barmaid }\end{array}$ \\
\hline $\begin{array}{l}\text { Social Rehabilitation Department of Disabled } \\
\text { People of Working Age }\end{array}$ & $\begin{array}{l}\text { - Head of the Department } \\
\text { - Social Work Specialist } \\
\text { - Psychologist } \\
\end{array}$ \\
\hline
\end{tabular}

Discussion: The Comparative Research

Results Analysis Based on the Impact of

Organizational Culture on the Chief

Executive's Leadership Qualities

The interviewees consider organizational culture and leadership from the "Now" and "I would like" positions, i.e., the situation by three indicators at the moment, and from the position of the examinees - in the ideal future of the organization, respectively.

Table 3.

Center $1 \& 2$. The Average Score for Each Option in \%

\begin{tabular}{|c|c|c|c|c|c|c|c|c|}
\hline The most important characteristics of the organization & \multicolumn{4}{|c|}{ Center 1.} & \multicolumn{4}{|c|}{ Center 2.} \\
\hline "Now" & 18 & 15 & 44 & 23 & 19 & 20 & 39 & 22 \\
\hline "I would like to" & 29 & 25 & 35 & 11 & 30 & 19 & 34 & 17 \\
\hline \multicolumn{9}{|l|}{ General management style in the organization } \\
\hline "Now" & 21 & 15 & 38 & 26 & 34 & 25 & 24 & 17 \\
\hline "I would like to" & 24 & 20 & 31 & 25 & 37 & 21 & 25 & 17 \\
\hline \multicolumn{9}{|l|}{ Employee management style } \\
\hline "Now" & 14 & 22 & 38 & 26 & 10 & 34 & 26 & 30 \\
\hline "I would like to" & 21 & 18 & 41 & 20 & 37 & 22 & 23 & 18 \\
\hline
\end{tabular}


During the interview, most of the staff, which filled out the questionnaire, indicated the following characteristics of the organization.

\section{Organizational culture.}

1) The organization is focused on results. The main goal is to fulfil the state task. Employees are interested in fulfilling the terms of the state contract ("Now"- to a greater extent, and "I would like" -to a lesser extent)typical for both Centers).

2) The organization has its own characteristics. The friendly team ("Now" -to a lesser extent, and "I would like" -to a greater extent) is typical for both Centers).

3) The organization has a clear structure. The employees' actions are strictly controlled ("Now"- to a greater extent, and "I would like" to a lesser extent) - typical for both Centers).

4) The organization is ready for change. Employees are not afraid of innovations. ("Now"- to a lesser extent, and "I would like"- to a greater extent) - typical for both Centers).

These indicators are typical for both Centers and testify to the bureaucratic structure of these organizations. Key values of success - adequate distribution of decision-making powers, standardized rules and procedures, control and accounting mechanisms. The organization is focused on results. The figures obtained can be explained by the fact that employees are interested in fulfilling the state contract terms since their material well-being depends on it (effective contract). If the main goal is not achieved, it can lead to reorganization and staff reduction.

Leadership style in the organization.

1) The leadership style in the organization is an example of a business-like and resultsoriented approach ("Now" - to a greater ex- tent, and "I would like" - to a lesser extent, typical for Center 1).

The leadership style in the organization is aimed at promoting employees ("Now" to a lesser extent, and "I would like" - to a greater extent, typical for Center 2).

2) The leadership style is an example of clear coordination and planned business management ("Now"- to a greater extent, and "I would like" - to a lesser extent, typical for Center 1).

The leadership style in the organization is an example of a business-like approach and is result-oriented ("Now" - to a lesser extent, and "I would like" - to a greater extent, typical for Center 2).

3) The leadership style in the organization is aimed at promoting employees ("Now" - to a lesser extent, and "I would like"- to a greater extent, typical for Center 1).

The leadership style in the organization is an example of innovation. ("Now" to a greater extent, and "I would like to" to a lesser extent, typical for Center 2).

4) The leadership style in the organization is an example of innovation. ("Now" to a lesser extent, and "I would like" to a greater extent, typical for Center 1).

The leadership style is an example of clear coordination and planned business management ("Now" and "I would like" are equal, typical for Center 2).

Center 1. The leadership style in the organization can be referred to as the culture of power. It depends on the core of power and travels outwards in the form of waves. The control is carried out by the centre through people (apparatus) selected for these purposes, working by certain rules and techniques and a small share of bureaucracy; decisions are made, for the most 
part, as a result of a balance of influences, rather than logic. The figures suggest that managers are result- oriented, no matter how results were obtained. There is no interest in understanding how each department works. Recommendations: the management should not only be able to coordinate and systematically conduct business, but also provide assistance to employees in solving the tasks.

Center 2. The leadership style in the organization can also be referred to the culture of power, but there are significant differences. The organization can respond rapidly to developments but largely depends on the decisionmaking by people from the Center, who seek to attract people inclined to politics, poweroriented, risk-loving, and underestimating security. These cultures rely on individuals, but not on the advice of others. Public order execution is evaluated by results, and the means of obtaining them are treated tolerantly. The data obtained suggest that the leadership style in the organization is aimed primarily at fulfilling the public order for social services and at solving problems related to attracting social services recipients.

\section{Employee management style.}

1) The management style in the organization is marked by high requirements for employees and promotion of their achievements ("Now" - to a lesser extent, and "I would like" - to a greater extent, typical for Center 1) typical.

The management style in the organization is characterized by the encouragement of the entire team ("Now" - to a lesser extent, and "I would like" - to a greater extent, typical for Center 2).

2) The management style in the organization is identified by the requirements of subordina- tion and stability in relations ("Now" - to a greater extent, and "I would like" - to a lesser extent, typical for Center 1).

The management style in the organization is characterized by the encouragement of individual employees ("Now" - to a greater degree, and "I would like" - to a lesser extent, typical for Center 2).

3) The management style in the organization is characterized by the encouragement of individual employees ("Now" - to a greater extent, and "I would like" - to a lesser extent, typical for Center 1).

Management style in the organization is distinguished for subordination and stability in relations ("Now" - to a greater degree, and "I would like"- to a lesser extent, typical of Center 2).

4) Management style in the organization is remarkable for the encouragement of the entire team ("Now" - to a lesser extent, and "I would like"- to a greater extent, typical for Center 1).

Management style in the organization is characterized by high employees requirements and promotion of their achievements ("Now" - to a greater extent, and "I would like" - to a lesser extent, typical for Center 2).

The obtained data shows that the staff management style in both Centers is liberal, i.e. a combination of authoritarian and democratic management styles. This suggests that the figure of the manager is formal, and he performs a mediation role between employees and senior management. The headsets tasks and fades into the background, providing an opportunity for independent task implementation. But in the Center 1 , the liberal style is biased towards the authoritarian style, when the decisions are generally 
made by the head, a lot of energy is spent on control, but not of all employees.

Given the survey results, we can draw the following conclusions:

1. Center 1 and Center 2 have a formalized and structured workplace. Managerial procedures rule employees. It is crucial to maintain the main course of the organization. The organization combines formal rules and official policy. Her long-term concerns are to ensure stability and development results. Both reputation and success are common concerns. The outlook focus is set on solving the tasks and achieving visible goals.

Recommendations: in the face of changing regulatory documentation, organize seminars for employees, training so that they should be ready for innovations.

2. The leadership and employees management style in organizations are different. Centre 1 is focused on fulfilling public order in any way possible. Requirements for employees are too high. There is strict control over the labour discipline and organization of the delivery service process, but not for all personnel. Not all employees are encouraged. The leader is a fighter; he is aggressive and determined. The leadership is based primarily on managing information. Achieving victory is the dominant goal; the focus of attention is on the external competitors and organization position in the area. There is an actively encouraged control. The basis of its influence is managing calendar schedules, appointments, finance, resource allocation, etc.

Recommendations:

- there is a need for better coordination and planning business management, to be an example of innovation;

- to fulfil the public order (fulfil the plan for the services rendered and attract primary users of social services), it is necessary to create trusting relationships in the team, encouraging not only some individual employees but the entire team. To promote the employees' initiative in every possible way. To assist in obtaining, improving education and skills.

Center 2 first and foremost renders all possible assistance to employees under the current difficult circumstances to fulfil the public order. Success is achieved due to good feelings towards the recipients of social services and caring for people. The leader has extensive experience, is partly a mentor, people and process-oriented person, settling conflicts and looking for consensus. $\mathrm{He}$ is an expert in various areas of activity, regulates the processes of interaction within the organization and outside of it. He encourages the entire team, but in the person of individual employees for personal merits, so that in the future everyone would strive for achievements.

Recommendations: the manager should listen to the opinion of the team, make decisionmaking collegial, and fully participate in achieving the results. This would serve as an additional incentive and motivation for employees.

Analyzing the organizational nature of culture, we came to the conclusion that the management style of the supervisory personnel and the presence of certain leadership qualities depend on its typology.

Let us analyze tests results by the degree of administrative or leadership abilities of the Center 1 leaders (see Table 4). 
Table 4.

Results of the Test

\begin{tabular}{|c|c|l|c|l|c|}
\hline № & $\begin{array}{c}\text { Even Position, } \\
\text { points }\end{array}$ & $\begin{array}{c}\text { Even Position, } \\
\%\end{array}$ & $\begin{array}{c}\text { Odd Position, } \\
\text { Points }\end{array}$ & $\begin{array}{c}\text { Odd Position, } \\
\%\end{array}$ & $\begin{array}{c}\text { Total } \\
\text { Points }\end{array}$ \\
\hline 1 & 37 & 31,50 & 79 & 68.10 & 116 \\
\hline 2 & 45 & 39,13 & 70 & 60,87 & 115 \\
\hline 3 & 31 & 32,63 & 64 & 67,37 & 95 \\
\hline 4 & 62 & 57,41 & 46 & 42,59 & 108 \\
\hline 5 & 86 & 48,86 & 90 & 51,14 & 176 \\
\hline 6 & 48 & 38,71 & 76 & 61,29 & 124 \\
\hline 7 & 47 & 37,60 & 78 & 62,40 & 125 \\
\hline 8 & 35 & 36,08 & 62 & 63,92 & 97 \\
\hline 9 & 63 & 56,25 & 49 & 43.75 & 112 \\
\hline Average & 50,44 & 42,51 & 68,22 & 57.49 & 118,66 \\
value & & & & & \\
\hline
\end{tabular}

The odd positions score implies the tendency to leadership; even positions score - to administration.

The abilities rank is determined by correlating the points scored on the corresponding position to the total amount of points and multiplication by $100 \%$.

On the basis of testing, we analyze the leadership and administrative abilities of the Center 1 leaders. Seven people, from the management team, consider themselves to be leaders in the organization because their odd position score is more than 50 points. Two people have developed administrative skills, with an even position score of more than 50 points. All testers have leadership skills.

The degree of leadership abilities prevails over the degree of administrative abilities development of the Center's management staff.

Conclusion. The Center 1 survey and testing suggest that the organizational culture is bureaucratic; authoritarian management style dominates; the main part of branch managers are leaders with administrative abilities.
Sociological Research on the Impact of

Organizational Culture on the Manager's

Leadership Qualities Exemplified by a

Comparative Analysis of St. Petersburg

Social Services and Organizations

Sociological research was conducted by questionnaire. The research involved 30 people. The survey was conducted among the leaders of St. Petersburg social organizations.

The questionnaire is a list of multiple choice 11 questions, choosing one of the proposed options the respondent expressed his attitude to this choice in the form of a description, which is more consistent with his views.

Professional activity value in the respondents' life. The survey revealed that respondents, for the most part, appreciate the opportunity to display their abilities, knowledge and skills, and a sense of usefulness. At the same time, $10 \%$ of respondents are satisfied with decent earnings. For $25 \%$, it is important that they can decide for themselves what to do and how. Most of the respondents have difficulty get down to busi- 
ness that they have no interest in. Nevertheless, they note that they have more perseverance than abilities and that they can be unbearably boring without their favourite work. That is, ambitiousness and purposefulness are inherent in managers; they have also a creative component, authoritativeness, initiative. These qualities are inherent in the harmonious personality type (according to A. F. Lazursky), passionate (according to Heymans - R. Le Senn), an innovator, rationalist (according to A. B. Reznik). The ability to exercise their knowledge and abilities in their professional activities is very important for the survey participants. This may be due to the fact that people could not find themselves in another area (creativity, family life, political life), but the creative and constructive principle in them predominates and makes them achieve heights, strive for goals. They need to be wanted by society; they are ready to devote themselves to work and reveal at the same time their talents and abilities. But the majority of respondents treat uninteresting from their point of view jobs without enthusiasm, although they force themselves to deal with them, which is suggestive of the socalled "creative vein" and considerable willpower of the interviewed executives. Ideally, they need inspiring, unusual, interesting projects to work with, but in everyday life, they are fully capable of organizing themselves and the team to doing routine work.

\section{Leadership style}

Judging by the answers to the question "Do you think a good leader:

a) takes counsel with subordinates regularly, especially experienced workers?

b) allows his subordinates give not only advise but instructions to their supervisor.

c) does not allow his subordinates to advise, and especially object?"
The majority of $85 \%$ of respondents chose "a", that is, they regularly take counsel with the experienced subordinates. It speaks of dedication, the ability to value professional and human qualities of other people and to sacrifice personal motives in the interests of the cause.

As for authoritativeness, $62 \%$ of respondents answered clarifying the degree of its expression: in crisis, they are switching to more rigid methods of management, and if they are unaware sometimes, they turn to others for help. The need for power is one of the primary human instincts, so the desire to insist on their point of view and manage people helps to overcome difficulties in moving towards the intended goal.

The answers to the question of how managers react on the unavailability of subordinates (cancel a meeting) show that $23 \%$ of respondents almost never cancel a scheduled meeting, even if it turns out that employees are not ready for any reason, 23\% answered that almost always in such cases they cancelled the meeting, and $54 \%$ did it sometimes or often.

The survey results on the interaction between the management and subordinates indicate that the management is either democratic, or organizational, or innovative-analytical . The leader character qualities form a certain management style. Thus, leaders who value external activities, spirituality, and altruism create a team at work that is capable of achieving their goals with enthusiasm and high efficiency. They are very committed to the cause and value loyalty in their subordinates, and while realizing the interests of the organization, do not forget about the individuals' interests, which contributes to the cohesion of the team. Emotional, active leaders, concentrating efforts in one direction, pay attention to innovative methods of work, thus creating in a 
team setting for innovation, modern technology and high performance. They encourage creativity, initiative quick decision-making, practice brainstorming. Finally, leaders who prioritize high professionalism and mutual assistance manage their organization in a democratic style, focusing primarily on the human factor. Relationships in the team are based on mutual assistance.

The organization management style depends on the manager personality type, as well as on the team with its diversity of characters and temperaments, the presence of an informal leader in the team, standard or emergency situation, etc.

The survey revealed basic, in the opinion of the respondents, skills that a successful leader should possess.

The first opinion is the leader should be an example worthy of imitation. Since truly impressive results are achieved only in cooperation, and in no case under pressure, only when employees admire their leader, ready to follow him, trust him. To do this, according to respondents, a manager must be, so to speak, a psychologist, to understand what employees need at the moment, to hear them, to be able to motivate them to work.

The unanimous opinion was expressed in this way: a successful leadership style is impossible without such traits of character as purposefulness, determination, responsibility, creativity. Most of the respondents are also confident that only a free person, a self-confident and selfreliant person can sufficiently possess these qualities, though there are few such highly efficient managers in Russia today.

The sociological study on identifying the interdependence of the model components for implementing effective management in social institutions in St. Petersburg showed the following results.

1. Management style in the organizations under study is various. Center 1 exercises a strict control to fulfil public order task in many possible ways. The requirements for employees are too high. There is strict control over the discipline in the team and the process of rendering service, but not for all personnel. Not all employees are encouraged. The leader is a fighter; his character is aggressive and determined. The leadership is based on information management. Achieving results is the dominant goal; the focus of attention is on the external competitors and the position their organization occupies in the area.

In Center 2, there is all possible assistance to employees in the current difficult circumstances to fulfil the public order. The manager has extensive experience; he is partly a mentor, a people and process oriented person settling conflicts and looking for consensus.

It is revealed, the type of organizational culture in the considered social institutions is bureaucratic; dominated by an authoritarian management style; the main part of branch managers are leaders with organizational skills.

2. The sociological research on identifying the interdependence of management style and manager personality type in social institutions revealed that the passionate personality type, managing in an innovative-analytical style contributes to greater efficiency of the organization's activities. Such leaders are active, focusing on innovative methods of work, encourage innovation in work, modern technologies and high performance, successfully applying brainstorming. Innovative and analytical management style also has these characteristics. 
Recommendation

The materials of the paper are useful for those who deal with the theory and methodology of sociology management, as well as for the development of new courses and seminars in leadership, management theory and practice, personality sociology and philosophy.

\section{Acknowledgements}

The detailed results of the paper are reflected in the following monograph of the author: "Social Technologies for the Formation of Leadership Qualities Among Future Leaders in the University Environment", which is the winner of the I International Competition for the Best Scientific and Educational Publication "Academus" in the nomination "Social Sciences, Education and Pedagogy" (Moscow, 2016). The contest was organized by the International Foundation of Development of Science and Education (IFDSE) in cooperation with the Infra-M group of companies.

\section{REFERENCES}

Aleshin, A. A. (2015). Rol' enniagrammi lichnosti $v$ sisteme upravleniya na sovremennom etape (The Role of Personality's Enneagrams in the Management System on the Modern Stage, in Russian). Virtual vestnik of Rostov socialeconomic university, 3(4), 393-401.

Aleshina, L. A., \& Zaglada, T. P., (2016). Issledovaniya organizacionnoi cultury predpriyatiya (Researches of the Enterprise Organizational Culture, in Russian). Young scientists, 18, 222-227.

Anchtoff, I. (1989). Strategicheskoe upravlenie
(Strategic Management, in Russian). Moscow: Economica.

Bushkova-Shiklina, E. V., (2012). Cennostnye indikatory lichnosti $v$ deyatel'nosti rukovoditelya (The Personality's Values Indicators in the Management Activity, in Russian). Moscow: INFRA-M.

Dessler, G. (2003). Upravlenie Personalom (Personnel Management, in Russian). Moscow: Binom.

Fiedler, F. E., (1972). The Effects of Leadership Training and Experience: A Contingency Model Interpretation. Administrative Science Quarterly, 17(4), 453-470.

Kameron, K. S., \& Quinn R. E. (2001). Diagnostika $i$ izmenenie organizatsionnoi kul'tury (Diagnostic and Change of Organizational Culture, in Russian). Sankt-Petersburg: Piter.

Karabushenko, N. B., (2013). Elitoorientirovannaya deyatelnost' lichnosti $v$ sisteme upravleniya (Elite-Oriented Personality's Activity in Management System, in Russian). RUDN Journal of Sociology, 2, 150-157.

Klukovkin, V. N., (2008). Lichnost' rukovoditelya i motivaciya ego deyatel'nosti (The Personality's Head and Motivation of his Activity, in Russian). Biysk: Polzunov Altai State Technical University Publication.

Koestenbaum, P., (1991). Leadership: The Inner Side of Greatness. A Philosophy for Leaders. San-Francisco: JosseyBass.

Korotkov, E. M. (2002). Organizacionnoe povedenie (Organizational Behavior, in Russian). Moscow. Tumenj.

Oganyan, K. K. (2014). Socialnie tekhnologii formirovanija liderskix cachevstv u budushix rukovoditelej $v$ vuzovskoj srede 
(Social Technologies for Forming Future Leaders Qualities in University's Areas, in Russian). Moscow: INFRAM.

Oganyan, K. K. (2015). Analiz lichnosti v istorii rossiiskoi sociologii: istoriya $i$ sovremennost' (Personality Analysis in Russian Sociology: History and Modernity, in Russian). Moscow: INFRA-M.

Oganyan, K. K. (2018). Sociologicheskij analiz integraljnij modeli lichnosti rukovoditelja (Sociological Analysis of Leader's Personal Integral Model: Theory and Practice). WISDOM, 2(11), 110120.

Oganyan, K. K., (2016). Methodologiya integral'noi teorii lichnosti (The Methodology of Personality's Integral Theory, in Russian). Sociology and Right, 4(34), 59-66.

Oganyan, K. K., (2016). Mezdishiplinarnye issledovaniya lichnosti v sociologii: sravnitel'nyi analiz (Multidisciplinary researches of personality in sociology: comparative analyses, in Russian). Moscow: INFRA-M.
Oganyan, K. M. (2013). Regulyatori social'nogo deistviya $v$ organizacionnoi cul'tury organizacii (Social Active Regulators in Enterprises Organizational Culture, in Russian). Policy and Sociology Piece, 7, 72-76.

Shejn, E. (2002). Organizacionnaya cul'tura $i$ liderstvo (Organizational Culture and Leadership, in Russian). Sankt-Petersburg: Piter.

Tannenbaum, A. (1962). Control in Organizations: Industrial Adjustment and Organizational Performance. Administrative Science Quarterly, 7(2), 236-257.

Tikhonov, A. V. (2009). Teoreticheskie osnovy social'noi regulyacii upravlencheskogo tipa (Theoretical Foundation of Social Regulation of Management Type, in Russian). Personality. Culture. Society, 11(3), 260-269.

Zhuravlev, A. L. (2004). Psikhologiya upravlencheskogo vzaimodeistviya (Psychology of Management Interaction, in Russian). Moscow: Institute of Psychology RAN. 